\title{
もやもや病一血行再建術の適応と今後の課題一
}

\author{
川島 明次 ${ }^{1)}$, 山口 浩司 ${ }^{2)}$, 岡田 芳和 ${ }^{3)}$, 川俣 貴一 2 ) \\ 1）東京女子医科大学附属八千代医療セン夕一脳神経外科，2）東京女子医科大学脳神経外科，3）聖路加国際病院脳神経外科
}

\section{Moyamoya Disease : Indication for Revascularization Surgery and Future Prospects}

\author{
Akitsugu Kawashima, M.D., Ph.D. ${ }^{1)}$, Koji Yamaguchi, M.D., Ph.D. ${ }^{2)}$, Yoshikazu Okada, M.D., Ph.D. ${ }^{3)}$, and \\ Takakazu Kawamata, M.D., Ph.D. ${ }^{2)}$ \\ 1) Department of Neurosurgery, Tokyo Women's Medical University Yachiyo Medical Center, 2) Department of Neurosur- \\ gery, Tokyo Women's Medical University, 3) Department of Neurosurgery, St. Luke's International Hospital
}

As a result of the recent advances in research of moyamoya disease, diagnostic criteria in Japan were revised in 2015. Several studies have proved that direct extracranial-intracranial (EC-IC) bypass plays essential role not only for reduction of ischemic stroke, but also of rebleeding risks in adult patients. Subanalysis of Japan Adult Moyamoya Trial indicates that patients with bleeding in the posterior circulation territory are particularly at higher risk of rebleeding and obtain greater benefits from a direct EC-IC bypass. However, some topics related to direct EC-IC bypass for patients of moyamoya disease remain still unsolved. It is difficult to distinguish the presence of intracranial arteriosclerosis in some patients of supposed moyamoya disease unless RNF213 is clarified as a susceptibility gene. The surgical management in patients of rapidly progressing moyamoya disease who suffer from repeated ischemic stroke in a short period of time remains unsolved. Direct EC-IC bypass provably allows to prevent aggravating ischemic stroke, however perioperative ischemic complications cannot be ignored and best treatment including direct EC-IC bypass cannot completely prevent ischemic stroke, especially in some young pediatric patients. Hyperperfusion has been reported to be one of the essential phenomena which causes focal intracranial hemorrhage or some other postoperative complications. Recently some specific radiographical changings after direct EC-IC bypass in patients of moyamoya disease, such as vasogenic edema, high intensity in the sulcus on fluid-attenuated inversion recovery (FLAIR)images, and subcortical low intensity on FLAIR images have been reported. These radiographical changes appear within several days after operation with or without transient neurologic events and disappear within several weeks. The mechanism of these findings and their relationship to postoperative complications such as transient neurologic events, ischemic stroke, and focal intracerebral hemorrhage remains unclear. A future study of cognitive impairment in patients of moyamoya disease and effectiveness of direct EC-IC bypass to improve it should be conducted. After an accurate evaluation of cognitive impairment including radiographical findings in patients of moyamoya disease, appropriate indication of direct EC-IC bypass to improve that deficit may be established. A future study of the natural history of asymptomatic moyamoya disease will also be of value to clarify indications of direct EC-IC bypass.

(Received February 14, 2018; accepted March 9, 2018)

Key words : moyamoya disease, extracranial-intracranial bypass, ischemic onset, hemorrhagic onset, cognitive dysfunction

Jpn J Neurosurg（Tokyo）27：522-527, 2018

連絡先：川島明次，干 276-8524 八千代市大和田新田 477-96 東京女子医科大学附属八千代医療セン夕ー脳神経外科

Address reprint requests to: Akitsugu Kawashima, M.D., Ph.D., Department of Neurosurgery, Tokyo Women's Medical University Yachiyo Medical Center, 477-96 Owadashinden, Yachiyo-shi, Chiba 276-8524, Japan 


\section{はじめに}

もやもや病は, 原因不明の脳主幹動脈閉塞性疾患であ る. 両側性に内頝動脈終末部を中心に狭窄/閉塞が進行 していき，側副血行路として異常血管網（もやもや血管） が発達する ${ }^{18)}$. 本疾患は進行性で, 脳梗塞や脳出血を繰 り返し，脳萎縮を呈する予後不良例がある一方で，直接 血行再建術を中心とした血行再建術が有効であり, 適切 なタイミングで治療が行われた多くの症例で機能的，社 会的予後は良好である。近年，もやもや病治療に関する 研究の進歩は著しく，2015 年には診断基準が改定され た。本稿ではもやもや病に対する直接血行再建術を中心 に, 最近の知見と未解決問題, さらに今後の展望につい て述べる。

\section{最近の知見}

\section{1 もやもや病新診断基準}

診断は $1.5 \mathrm{~T}$ 以上の MRA でも可能だが, 片側性病変や 動脈硬化を合併する病変に対しては脳血管撮影が必須で ある。頭蓋内内頝動脈終末部を中心に狭窄/閉塞がみら れ，もやもや血管が動脈相で認められる。新診断基準で は，(1)もやもや病 (両側型), (2)もやもや病 (片側型), (3)類もやもや病，(4)非もやもや病，とそれぞれを明確に 区別している，類もやもや病は自己免疫疾患，髄膜炎， 脳腫瘍，ダウン症，甲状腺機能立進症などの疾患を合併 する場合である。非もやもや病とは, 動脈硬化が原因と 考えられる例と頭部への放射線照射の既往がある例であ り, もやもや病/類もやもや病から除外される. 重症度分 類が設けられ, 成人例では Barthel Index が 85 点以下, 画像上脳梗塞なぞの器質的変化を伴った高次脳機能障 害，手術適応または術後 5 年以内，再発例のいずれかを 満たすことが重症例の要件である，小児例では小児慢性 疾患に準じており, 運動障害, 知的障害, 意識障害, 自 閉傾向，行動異常，痤攣発作などを有することが要件で ある。

\section{2 虚血発症例に対する血行再建術}

脳虚血症状発症例，および SPECT，PET などで脳循 環代謝異常を示す症例が手術適応である，小児例に関し ては症状が急速に進行することがあり, 将来の脳卒中予 防のためにも手術適応は広く考えられている。手術時期 は, 周術期合併症を回避する理由から通常脳梗塞急性期 を避け, 症状安定期に行う。具体的には最終発作が出て から 2 3 週間以上間隔を開けることが多い. 一方で, 急
速進行例に対する手術時期に関してはさまざまな問題が あり，後述する。術式は直接血行再建術（複合法含む） と間接血行再建術があるが，技術的に可能なら直接血行 再建術のほうが望ましい。術直後から治療効果を得ら れ, 脳梗塞予防効果, angiographical 治療効果が高く ${ }^{6)}$, 中大脳動脈領域のみならず前大脳動脈領域まで虚血領域 に応じて血行再建を行うことも可能である ${ }^{10)}$ 。周術期合 併症の頻度は直接血行再建術と間接血行再建術は同等と 報告されている ${ }^{8)}$ 。術後合併症として，直接血行再建術 では局所過灌流による一過性局所神経脱落症状や頭蓋内 出血，遠隔部虚血性合併症が問題となる。一方で間接血 行再建では脳表面に敷き込んだ組織による mass effectや 術後出血，周術期脳梗塞などがある．虚血発症もやもや 病に対して血行再建術は，脳梗塞予防効果だけでなく， 術後 ADL 改善, 長期的高次脳機能改善, 脳循環代謝改善 が報告されている。もやもや病特有の朝方に起こる嘔気 を伴う強い頭痛（特に小児例で多く認められる）に対し ても，直接血行再建術の有效性が報告されている ${ }^{17)}$.

\section{3 出血発症例に対する血行再建術}

近年，本邦発の多施設前向きランダム化比較研究であ る Japan Adult Moyamoya（JAM）trialにより，出血発症 成人もやもや病に対する両側半球への直接血行再建術の 有効性が明らかになった ${ }^{16)} .1$ 年以内に出血を発症した 成人もやもや病に対して, 直接血行再建術は内科治療と 比較して有意に重度の後遺症または死亡（mRS 3〜6）と なるような event が少なく，かつ再出血が少ないことが 証明された。再出血の頻度は手術群で $2.7 \% /$ 年，内科治 療群で 7.6\%/年だった。 JAM trial の sub 解析によると, 出血した部位を前方循環系と後方循環系に分類すると， 後方循環系に出血したほうが有意に再出血しやすく，ま たこのような症例には直接血行再建術による再出血予防 効果も顕著であることが証明された ${ }^{20)}$ 。さらに，詳細な angiographical な検討では，後方循環系の出血症例，およ び再出血症例には anterior/lateral posterior choroidal artery が関与するもやもや血管と paraventricle の medullary artery の natural anastomosis を伴っている症例，およ び後大脳動脈の狭窄を伴っている症例が多かった ${ }^{3)}$ 。自 験例でも直接血行再建術後にバイパスからの側副血行路 の発達に伴い，もやもや血管だけでなく上述の choroidal anastomosis の減少が認められた症例があった（Fig. 1) がそそもそも angiographicalに choroidal anastomosis を同 定することは困難な症例も多く，さらなる検討が必要と 思われる。出血発症もやもや病に対する直接血行再建術 の再出血予防効果の mechanism としては注目に值する. 

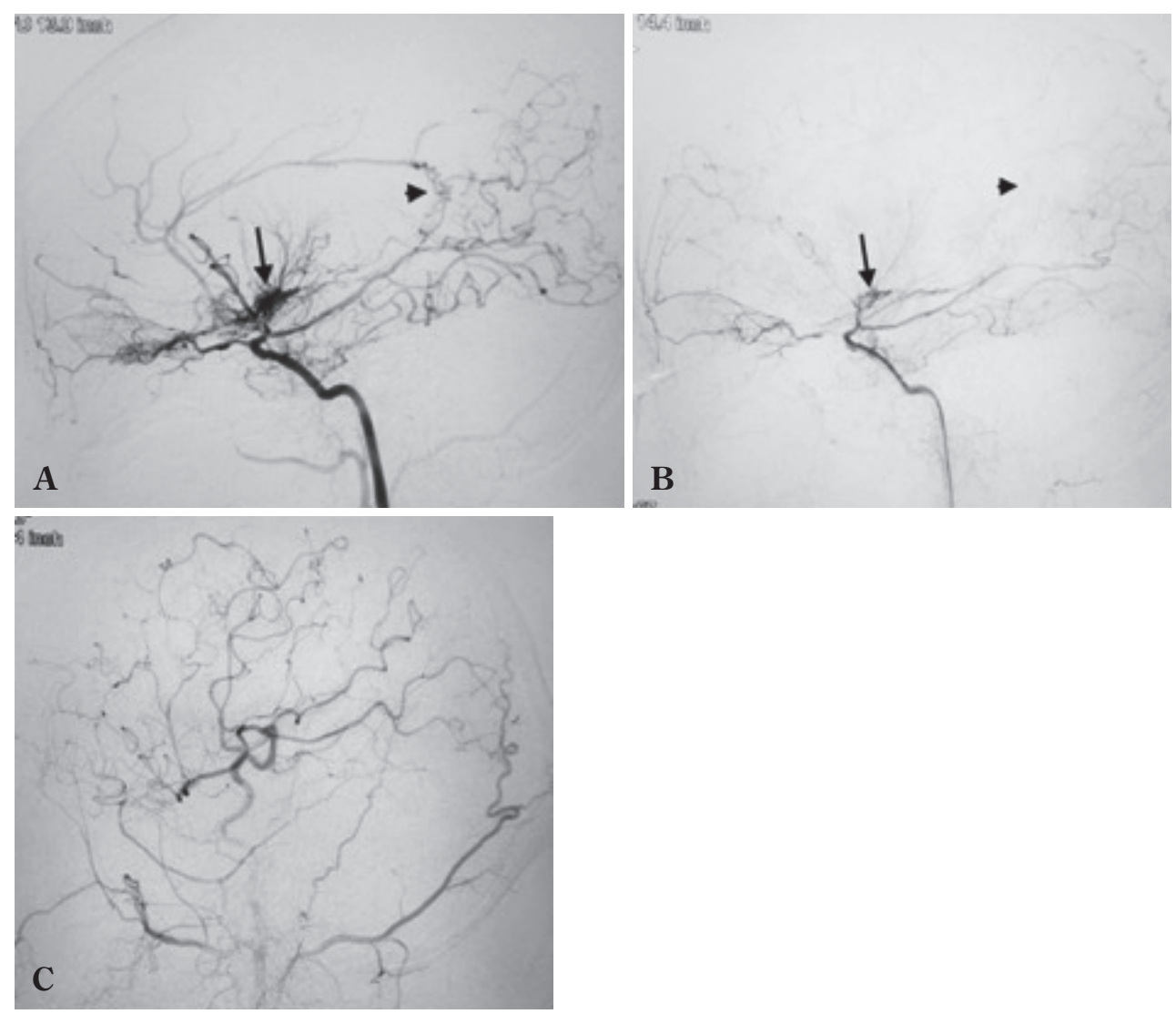

Fig. 1 A 37-year-old woman presenting with intracerebral hemorrhage

The preoperative left internal carotid angiogram demonstrating severe stenosis in the internal carotid bifurcation with moyamoya vessels (arrow) and the medullary arteries (arrowhead) fed by the anterior choroidal artery（A). The left internal carotid angiogram (B) and the left external carotid angiogram (C) six months after superficial temporal artery (STA) -middle cerebral artery bypass showing that most of the moyamoya vessels and the medullary arteries disappeared (arrow and arrowhead) with extensive blood flow from the STA graft.

\section{末解決の問題}

\section{1 もやもや病の診断（もやもや病と動脈硬化性疾} 患)

臨床の現場では, もやもや病と動脈硬化性疾患との鑑 別が困難な症例が珍しくなく, 厳密な意味での両者の鑑 別は不可能と思われるものもある，上述したように，も やもや病の診断はあくまでも形態学的に行う一方で, 動 脈硬化の診断は病理学的所見に基づくためである。もや もや病の感受性遺伝子として RNF213 が同定され，診断 にも遺伝子的指標が試みられている。 RNF213 変異は日 本人健常者では $2 \%$ ，もやもや病症例には 80 90\%に認 められるものの, 動脈硬化による脳主幹動脈閉塞性症例 にも20\%認められるといわれている，RNF213 だけでは 発症のメカニズムは説明できない。これに対して Kuroda
$ら^{14)}$ は MRI 3D-constructive interference in steady state （CISS）画像を用いた両者の鑑別法を報告した。もやも や病の狭窄した内頝動脈終末部周囲の血管の外径は線維 性に狭窄している。こ机に対して動脈硬化性病変では血 管外径の狭窄はないことに着目し, MRI 3D-CISS を用い て血管の外径を計測することで両者の鑑別を試みた。い ずれの方法も課題はあるものの, 今後に期待できる.

\section{2 急速進行性もやもや病}

もやもや病は慢性に進行していく閉塞性疾患であり, 成人例では $1 / 4$ が, 小児症例では約半数が angiographical に進行するといわれている ${ }^{13)}$.この中で, 短期間に急速 に血管閉塞が進行, 脳梗塞を繰り返す急速進行症例が存 在する. 急速進行症例は 1 力月余りの間に脳梗塞を両側 に 2 度 3 度繰り返すことも珍しくない. 若年小巟症例, 

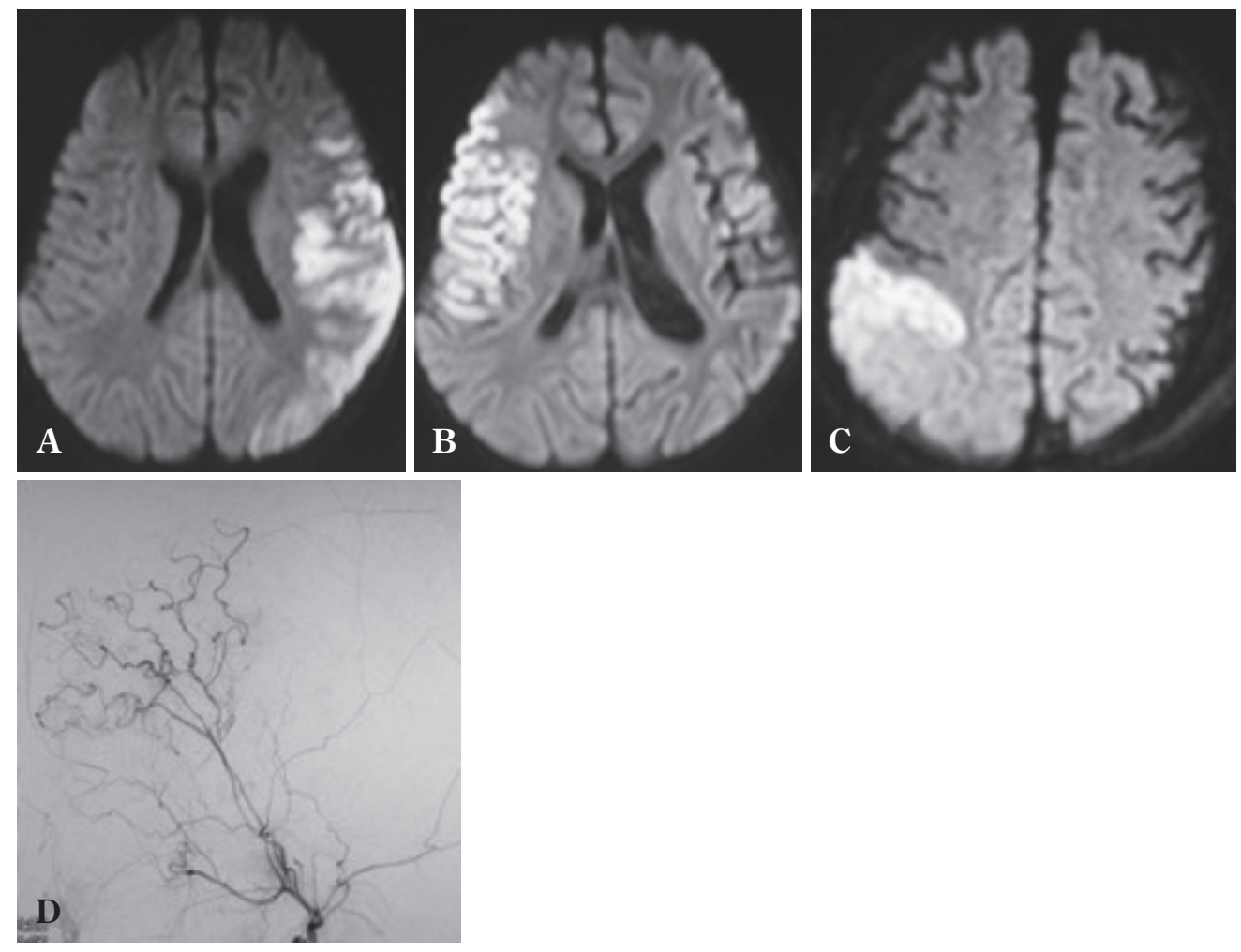

Fig. 2 A 2-year-old boy presenting with cerebral infarction in the left and the right middle cerebral artery (MCA) territories, respectively in two weeks

The left and the right superficial temporal artery-MCA bypass with indirect procedures were performed after 2 weeks and 7 weeks after the second episode, respectively. Cerebral infarction was repeated in the right parietal region one month after the right side operation. Diffusion weighted MR image at the first episode (A), the second episode (B), and the third episode (C). The right external carotid angiogram 8 days after the right side operation（D) demonstrating good blood supply from the STA graft in the right frontal region.

脳梗塞で発症などが危険因子として挙げられている一方

で，鈴木分類による病期や SPECT 上の重度の脳血流低 下は関係していない4)。病期が急速に進行し，予後に大 きく関係するこの時期の治療選択が重要である。現状で は，治療効果がすぐに期待できる直接血行再建術を中心 とした治療を行うことが最善と考えられるが，効果が不 十分な症例もある (Fig. 2)。手術待機中の脳梗塞再発率 が高いことから急性期/亜急性期血行再建術の選択枝が ある一方で，血行再建術による周術期脳梗塞のリスクも 無視できない，麻酔，ICU（PICU），病棟管理を含めた チームの総合力も不可欠である．治療のわずかな遅れが 大きな後遺症につながる恐れがあるため, 特に虚血発症 の若年小児例では，急速に脳虚血が進行していく可能性 を念頭に治療 management を行うことが重要である.

\section{3 術後画像変化, 合併症}

もやもや病に対する直接血行再建術後過灌流と術後一
過性神経脱落症状や局所脳内出血との関連が以前から指 摘されている2)。これに対する予測や予防のためのさま ざまな試みが行われているが199)，克服されていないの が現状である。筆者らは直接血行再建術症例全例に術直 後，鎮静下に SPECT を行っている。吻合部直下の皮質 下の血流上昇部に ROI を設定，対側比 2 倍以上を過灌流 と定義したところ, 成人では半数以上に過灌流が認めら れた（Fig. 3)。これらのうち症候性になるものは一部で はあるが，潜在性に合併症を呈する可能性がある。過灌 流の程度や部位と症状が必ずしも一致しないなど，不明 な点も多い. 近年, 直接血行再建術後早期に MRI 上のさ まざまな画像変化が報告されている，局所血管原性浮 腫, fluid-attenuated inversion recovery (FLAIR) image で の脳溝 high intensity, 皮質下 low intensity などである ${ }^{5)}$. 慢性的に低灌流/脳虚血状態になっているもやもや病の 脳血管は自動調節能が破綻しており，非常に脆弱で透過 性が充進していることが関係しているともいわれている 


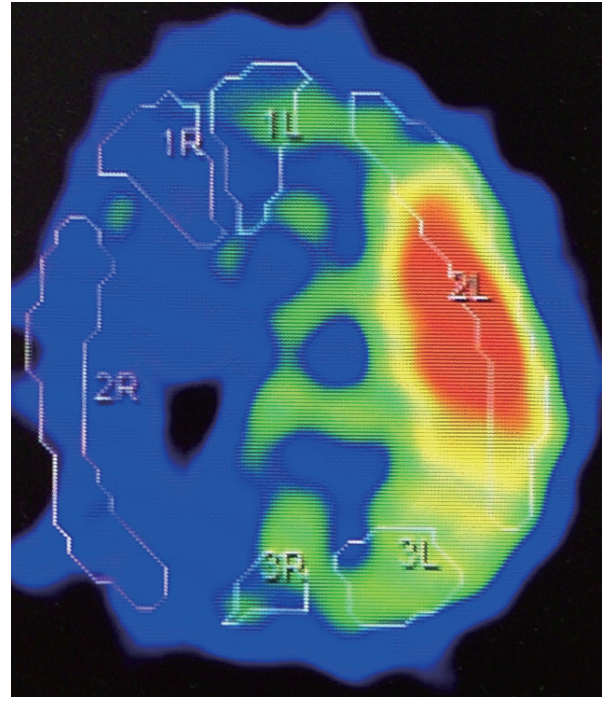

Fig. 3 A 37-year-old woman of moyamoya disease (Fig. 1)

Postoperative 123IMP SPECT demonstrating severe hyperperfusion in the left middle cerebral artery territory.

が，それぞれの mechanism や一元的に説明できるのか否 か, 前述の過灌流との関連など, 詳細は不明である. MRI 画像変化と術後一過性に出現する局所神経脱落症 状との関連も示唆されているが，否定的な報告もあ る ${ }^{15)}$. いずれも術後数日以内に出現し 1 数週間で消退 する.

\section{今後の展望}

\section{1 高次脳機能障害}

直接血行再建術後，もやもや病症例の高次脳機能障害 の改善を臨床現場で実感することは少なくないものの, 有効性は科学的に証明されていない，直接血行再建術の 高次脳機能改善効果を強調する報告7) がある一方で, Zeifert ${ }^{211}$ は $75 \%$ の症例で変化がなく, 残りの半数が改 善, 半数が悪化したと報告している. 高次脳機能障害に はさまざまな要因が複雑に影響しているため評価が難し く,さらに症例ごとに脳虚血領域が異なり，血行再建術 によって脳血流が増加する領域や範囲も異なる点が複雑 である。もやもや病症例の中には確実に直接血行再建術 によって高次脳機能障害が改善される症例があり，これ をいかに抽出するかが肝要である。本邦ではもやもや病 症例の放射線学的特徵と高次脳機能を評価する Cognitive Dysfunction Survey of the Japanese Patients with Moyamoya Disease（COSMO-JAPAN Study）が進行中であ
$3^{19)}$.もやもや病症例で高次脳機能障害を呈する mechanismについても, 近年さまざまなアプローチが行われて いる. Kazumata ${ }^{11)}$ は MRI を用いた微細な脳実質変化 から，もやもや病症例では灰白質よりむしろ白質線維に 広範囲な密度低下を認め, これが高次脳機能障害に関与 していると報告している.

\section{2 無症候性もやもや病}

無症候性もやもや病は脳梗塞/頭蓋内出血の年間発症 リスクが $3 \%$ といわれているが，詳細な自然経過は明ら かでない。“無症候性” は明らかな一過性脳虚血発作, 脳 梗塞，頭蓋内出血の既往がないものだが，脳虚血症状の 中には麻痺や失語などわかりやすいものばかりではな い. また，慢性虚血に伴う高次脳機能障害が出現してい る可能性があるが，これを正確に評価することは難し い. 現在, 無症候性もやもや病に対する Asymptomatic Moyamoya Registry (AMORE) study が進行中である ${ }^{12)}$. 本研究から一過性脳虚血発作, 脳梗塞, 病気の進行, 頭 蓋内出血などの 5 年間の発生割合が明らかになる。これ に脳血流評価など放射線学的検査を加えることにより， 無症候性もやもや病の中からリスクの高いものを抽出で きるかもしれない.さらに上述の高次脳機能評価法が定 まることにより，無症候性もやもや病の中に隠れている 潜在的な stroke リスクや症候を評価し, 高次脳機能障害 を含む脳虚血症状悪化, 脳梗塞や出血の予防に対する直 接血行再建術の役割が明らかにされることが期待される.

著者は日本脳神経外科学会への COI 自己申告の登録を完了 しております。本論文に関して開示すべきCOIはありません.

\section{文 献}

1) Fujimura M, Niizuma $K$, Inoue T, Sato K, Endo $H$, Shimizu $H$, Tominaga T: Minocycline prevents focal neurological deterioration due to cerebral hyperperfusion after extracranialintracranial bypass for moyamoya disease. Neurosurgery 74: 163-170; discussion 170, 2014.

2) Fujimura M, Shimizu H, Inoue T, Mugikura S, Saito A, Tominaga $\mathrm{T}$ : Significance of focal cerebral hyperperfusion as a cause of transient neurologic deterioration after extracranial-intracranial bypass for moyamoya disease : comparative study with non-moyamoya patients using $\mathrm{N}^{-}$-isopropyl$\mathrm{p}^{-}$[ (123) $\left.\mathrm{I}\right]$ iodoamphetamine single-photon emission computed tomography. Neurosurgery $68: 957-964$; discussion 964-955, 2011.

3) Funaki T, Takahashi JC, Houkin K, Kuroda S, Takeuchi S, Fujimura M, Tomata Y, Miyamoto S; JAM Trial Investigators: Angiographic features of hemorrhagic moyamoya disease with high recurrence risk : a supplementary analysis of the Japan Adult Moyamoya Trial. J Neurosurg 128: 777784,2018 
4) Funaki T, Takahashi JC, Takagi Y, Kikuchi T, Yoshida K, Mitsuhara T, Kataoka H, Okada T, Fushimi Y, Miyamoto S : Unstable moyamoya disease : clinical features and impact on perioperative ischemic complications. J Neurosurg 122 : 400-407, 2015.

5) Hamano E, Kataoka H, Morita N, Maruyama D, Satow T, Iihara K, Takahashi JC : Clinical implications of the cortical hyperintensity belt sign in fluid-attenuated inversion recovery images after bypass surgery for moyamoya disease. $J$ Neurosurg 126:1-7, 2017.

6) Han JS, Abou-Hamden A, Mandell DM, Poublanc J, Crawley AP, Fisher JA, Mikulis DJ, Tymianski M : Impact of extracranial-intracranial bypass on cerebrovascular reactivity and clinical outcome in patients with symptomatic moyamoya vasculopathy. Stroke $\quad 42:$ 3047-3054, 2011.

7) Jefferson AL, Glosser G, Detre JA, Sinson G, Liebeskind DS : Neuropsychological and perfusion MR imaging correlates of revascularization in a case of moyamoya syndrome. AJNR Am J Neuroradiol 27: 98-100, 2006.

8) Jeon JP, Kim JE, Cho WS, Bang JS, Son YJ, Oh CW : Metaanalysis of the surgical outcomes of symptomatic moyamoya disease in adults. J Neurosurg 128: 793-799, 2018.

9) Kawamata T, Kawashima A, Yamaguchi K, Hori T, Okada Y : Usefulness of intraoperative laser Doppler flowmetry and thermography to predict a risk of postoperative hyperperfusion after superficial temporal artery-middle cerebral artery bypass for moyamoya disease. Neurosurg Rev $\quad 34: 355^{-}$ 362 ; discussion 362, 2011.

10) Kawashima A, Kawamata T, Yamaguchi K, Hori T, Okada Y : Successful superficial temporal artery-anterior cerebral artery direct bypass using a long graft for moyamoya disease : technical note. Neurosurgery 67 (3 Suppl Operative) : ons145-149; discussion ons 149, 2010.

11) Kazumata K, Tha KK, Narita H, Kusumi I, Shichinohe H, Ito $\mathrm{M}$, Nakayama N, Houkin $\mathrm{K}$ : Chronic ischemia alters brain microstructural integrity and cognitive performance in adult moyamoya disease. Stroke $46: 354-360,2015$.

12) Kuroda S ; AMORE Study Group : Asymptomatic moyamoya disease : literature review and ongoing AMORE study. Neurol Med Chir (Tokyo) 55:194-198, 2015.
13) Kuroda S, Houkin $\mathrm{K}$ : Moyamoya disease : current concepts and future perspectives. Lancet Neurol $\quad 7: 1056-1066$, 2008.

14) Kuroda S, Kashiwazaki D, Akioka N, Koh M, Hori E, Nishikata M, Umemura K, Horie Y, Noguchi K, Kuwayama $\mathrm{N}$ : Specific shrinkage of carotid forks in moyamoya disease : a novel key finding for diagnosis. Neurol Med Chir (Tokyo) 55: 796-804, 2015.

15) Machida T, Nakano S, Ishige S, Ono J, Fujikawa A : Subcortical low-intensity lesions on fluid-attenuated inversion recovery images after revascularization surgery for moyamoya disease. World Neurosurg $98: 512-519,2017$.

16) Miyamoto S, Yoshimoto T, Hashimoto N, Okada Y, Tsuji I, Tominaga T, Nakagawara J, Takahashi JC ; JAM Trial Investigators: Effects of extracranial-intracranial bypass for patients with hemorrhagic moyamoya disease: results of the Japan Adult Moyamoya Trial. Stroke 45:1415-1421, 2014.

17) Okada Y, Kawamata T, Kawashima A, Yamaguchi K, Ono Y, Hori T: The efficacy of superficial temporal artery-middle cerebral artery anastomosis in patients with moyamoya disease complaining of severe headache. J Neurosurg 116 : 672-679, 2012.

18) Suzuki J, Takaku A : Cerebrovascular "moyamoya” disease. Disease showing abnormal net-like vessels in base of brain. Arch Neurol $20: 288-299,1969$.

19) Takagi Y, Miyamoto S, COSMO-Japan Study Group : Cognitive Dysfunction Survey of the Japanese Patients with Moyamoya Disease (COSMO-JAPAN Study) : study protocol. Neurol Med Chir (Tokyo) 55: 199-203, 2015.

20) Takahashi JC, Funaki T, Houkin K, Inoue T, Ogasawara K, Nakagawara J, Kuroda S, Yamada K, Miyamoto S ; JAM Trial Investigators: Significance of the hemorrhagic site for recurrent bleeding : prespecified analysis in the Japan Adult Moyamoya Trial. Stroke $47: 37-43,2016$.

21) Zeifert PD, Karzmark P, Bell-Stephens TE, Steinberg GK, Dorfman LJ : Neurocognitive performance after cerebral revascularization in adult moyamoya disease. Stroke 48 : 1514-1517, 2017.

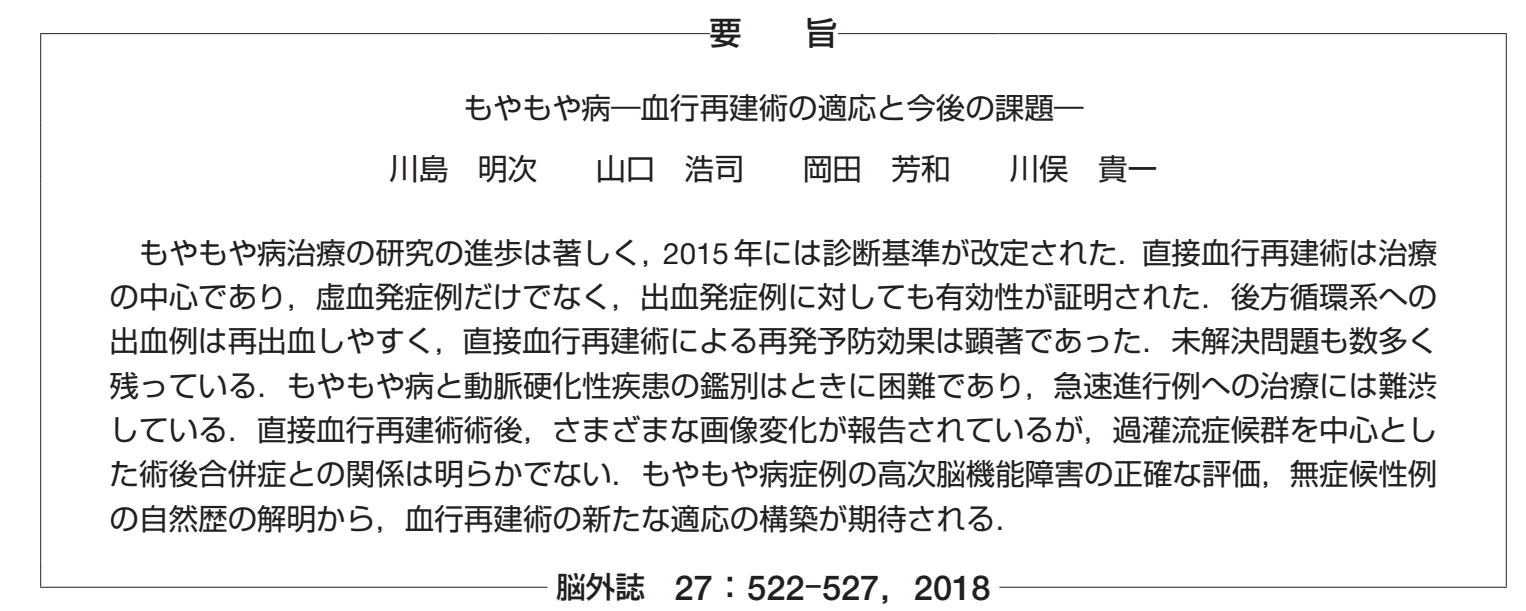

